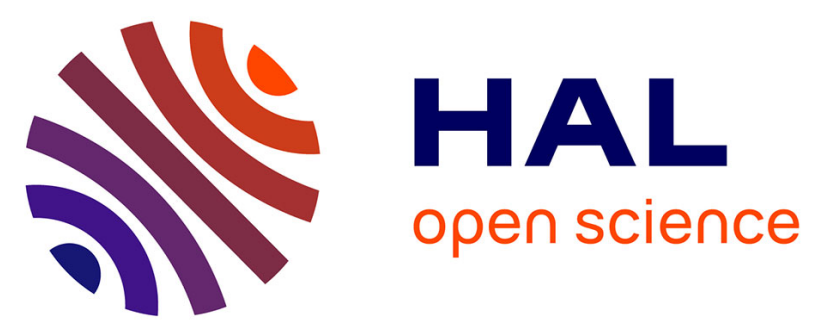

\title{
Osmoregulatory and endocrine relationships with chloride cell morphology and density during smoltification in coho salmon (Oncorhynchus kisutch)
}

Harold N. Richman, Susan Tai de Diaz, Richard, S. Nishioka, Patrick Prunet, Howard A. Bern

\section{To cite this version:}

Harold N. Richman, Susan Tai de Diaz, Richard, S. Nishioka, Patrick Prunet, Howard A. Bern. Osmoregulatory and endocrine relationships with chloride cell morphology and density during smoltification in coho salmon (Oncorhynchus kisutch). Aquaculture, 1987, 60, pp.265-285. 10.1016/00448486(87)90293-6 . hal-02728841

\section{HAL Id: hal-02728841 \\ https://hal.inrae.fr/hal-02728841}

Submitted on 2 Jun 2020

HAL is a multi-disciplinary open access archive for the deposit and dissemination of scientific research documents, whether they are published or not. The documents may come from teaching and research institutions in France or abroad, or from public or private research centers.
L'archive ouverte pluridisciplinaire HAL, est destinée au dépôt et à la diffusion de documents scientifiques de niveau recherche, publiés ou non, émanant des établissements d'enseignement et de recherche français ou étrangers, des laboratoires publics ou privés. 


\title{
Osmoregulatory and Endocrine Relationships with Chloride Cell Morphology and Density During Smoltification in Coho Salmon (Oncorhynchus kisutch)
}

\author{
N. HAROLD RICHMAN III ${ }^{1,3}$, SUSAN TAI DE DIAZ ${ }^{1,4}$, RICHARD S. NISHIOKA $^{1}$, \\ PATRICK PRUNET ${ }^{2}$ and HOWARD A. BERN ${ }^{1}$ \\ 'Department of Zoology and Cancer Research Laboratory, University of California, Berkeley, \\ Berkeley, CA 94720 (U.S.A.) \\ ${ }^{2}$ Laboratoire de Physiologie des Poissons, Campus de Beaulieu, Avenue du General Leclerc, \\ 35042 Rennes Cédex (France) \\ ${ }^{3}$ Present address: \\ Department of Zoology and Hawaii Institute of Marine Biology, University of Hawaii, \\ Honolulu, HI 96822 (U.S.A.) \\ ${ }^{4}$ Present address: \\ Universidad de Oriente, Nucleo de Sucre, Centro de Microscopía Electronica, Apartado Postal \\ 245, Cumana (Venezuela)
}

(Accepted 13 August 1986)

\section{ABSTRACT}

Richman, N.H.,III, Tai de Diaz, S., Nishioka, R.S., Prunet, P. and Bern, H.A., 1987. Osmoregulatory and endocrine relationships with chloride cell morphology and density during smoltification in coho salmon (Oncorhynchus kisutch). Aquaculture, 60: 265-285.

Chloride cell morphology and density in the gill and opercular membrane of coho salmon (Oncorhynchus kisutch) were examined during the 1982 and 1983 smolt-seasons for structural correlates to smoltification-associated changes in hypoosmoregulatory ability and plasma hormone levels. Although not synchronous in the two years, plasma thyroxine levels displayed two peaks each year. In 1982, changes in gill $\mathrm{Na}^{+}, \mathrm{K}^{+}$-ATPase activity were preceded by elevations in plasma thyroxine. In 1983, the increase in enzyme activity corresponded with the April increases in plasma thyroxine and prolactin. Seawater(SW) acclimation experiments showed discrete increases in SW tolerance which coincided with changes in gill enzyme activity. Although these data suggest a relationship between SW tolerance and plasma thyroxine levels, the patterns in the two years were different. A significant peak in plasma prolactin levels in April suggests possible involvement in the parr-smolt transformation.

Chloride cells were studied in the opercular membrane, a chloride cell-containing epithelium lining the branchial side of the operculum, and the gill epithelium. Opercular membrane chloride cells (1982), marked with a mitochondrion-specific fluorescent stain, increased nearly two-fold in late May, concurrent with the second increase in gill $\mathrm{Na}^{+}, \mathrm{K}^{+}$-ATPase activity and SW tolerance. Gill morphology was examined (1983) with scanning and transmission electron microscopy and light microscopy. Initially, the gill filament surface appeared rough but became smoother 
during smoltification and rough again toward the end of smoltification. Two mitochondrion-rich (chloride) cell types were present in the gill epithelium during smoltification. The electron-lucent type I cell contained large, circular mitochondria while the electron-dense type II cell contained thin, elongate mitochondria. Ultrastructurally, many type I cells appeared disrupted which may indicate cellular degeneration or a special response of type I cells to fixation. However, it was unusual to find either intact or disrupted type I cells after March. Chloride cell density (type I plus type II) remained constant during smoltification. The inability to distinguish between these cell types with the light microscope may have obscured changes in their individual densities. The data from both the opercular membrane and the gill epithelium and their relationship with gill $\mathrm{Na}^{+}, \mathrm{K}^{+}$-ATPase activity suggest that the development of SW tolerance during smoltification is partially due to changes in chloride cell enzyme activity and density. The presence of two mitochondrion-rich cell types is discussed with regard to their possible role in the hypoosmoregulatory changes which occur during smoltification.

\section{INTRODUCTION}

Following emergence from eggs laid in the gravel beds of freshwater (FW) streams, young coho salmon (Oncorhynchus kisutch) grow and develop into the parr stage. In the spring of their second year, the parr undergo smoltification, a complex series of morphological, behavioral, physiological, and biochemical changes which transform the stream-dwelling animal into a seawardmigratory smolt (for reviews, see Hoar, 1976; Folmar and Dickhoff, 1980; Wedemeyer et al., 1980; Barron, 1986). The transition from a FW hyperosmoregulator to a seawater ( $\mathrm{SW}$ ) hypoosmoregulator necessitates an alteration in osmoregulatory mechanisms. These mechanisms in most salmonid species develop coincidentally with smoltification. Their development is marked by increased SW tolerance and by elevated activity of gill $\mathrm{Na}^{+}, \mathrm{K}^{+}$-ATPase, an enzyme associated with gill ion regulation (for review, see Folmar and Dickhoff, 1980). Moreover, the alteration in SW adaptability may be hormonedependent: long-term SW survival correlates well with the portion of the smoltification-associated thyroxine peak completed prior to SW entry (Folmar and Dickhoff, 1981).

Studies on Atlantic salmon (Salmo salar) and steelhead trout ( $S$. gairdneri) suggest that gill chloride cells, the putative osmoregulatory cells, change in activity and/or density during smoltification (Parry, 1960; Threadgold and Houston, 1964; Wickes et al., 1983). Succinate dehydrogenase, a mitochondrial enzyme, increases in activity in gill tissue following smoltification in Atlantic salmon (Chernitsky, 1980). This increase is presumed to reflect changes in the mitochondrion-rich chloride cells in the gill. These observations are in agreement with the smoltification-associated increase in gill $\mathrm{Na}^{+}, \mathrm{K}^{+}$ATPase activity, an enzyme which has been shown in Atlantic salmon to be predominantly located in chloride cells (Langdon and Thorpe, 1984a).

In this study, gills were examined in coho salmon (Oncorhynchus kisutch) for structural correlates with physiological and biochemical changes associated 
with increased SW tolerance during smoltification. Chloride cells were studied in the gill filament and in the opercular membrane. Gill $\mathrm{Na}^{+}, \mathrm{K}^{+}$-ATPase activity and SW tolerance were used as indicators of the development of SWosmoregulatory mechanisms during smoltification. Plasma thyroxine and prolactin levels were also measured.

\section{MA'TERIALS AND METHODS}

\section{Animals}

The study was conducted in 1982 and 1983 with yearling (1981 and 1982 broodstock) coho salmon obtained from Iron Gate Hatchery (California Department of Fish and Game). Fish were held outdoors under natural photoperiod and temperature in raceways at Iron Gate (1982) or in recirculating raceways (wherein $10 \%$ of the water was replaced daily) at the University of California Bodega Marine Laboratory (1983). In 1982 fish were transported every 2 weeks to Berkeley where all experiments were performed. In $1983 \mathrm{SW}$ tolerance experiments and collection of plasma and gill samples were conducted at Bodega. Histological samples from animals were transported to Berkeley.

\section{Gill $\mathrm{Na}^{+}, \mathrm{K}^{+}$-ATPase analysis}

All eight gill arches were removed from the animals. Gill filaments were dissected free from the arch and placed in homogenizing medium $(0.3 \mathrm{M}$ sucrose, 0.02 M EDTA, 0.1 M imidazole) and frozen on dry ice. Samples were maintained at $-80^{\circ} \mathrm{C}$ until assayed, except for some samples held initially for a brief period at $-20^{\circ} \mathrm{C}$ in 1983 . The method of analysis has been published elsewhere (Zaugg, 1982).

\section{Plasma hormone and sodium analyses}

After stunning the animals by concussion, blood was collected from the severed caudal vasculature in heparinized (ammonium) microhematocrit capillary tubes (Dade; American Scientific Products, McGaw Park, IL). Plasma was obtained by centrifugation and stored in polyethylene vials at $-20^{\circ} \mathrm{C}$ until assayed. Plasma thyroxine was determined by radioimmunoassay as described by Specker and Richman (1984). Plasma prolactin concentration was determined by radioimmunoassay as described by Prunet et al. (1985; see also Hirano et al., 1985). Plasma sodium content was determined with a Perkin-Elmer Atomic Absorption Spectrophotometer (Model 290 or 290B; Perkin-Elmer, Mountain View, CA). Plasma sodium samples were prepared for analysis in duplicate by diluting 2 or $4 \mu \mathrm{l}$ of plasma in $10 \mathrm{ml}$ distilled water. Sodium stan- 
dards, prepared from oven-dried sodium chloride in distilled water, were used to calculate plasma sodium levels by least square regression analysis.

\section{$S W$ tolerance experiments}

Fish received from Iron Gate Hatchery $(1982)$ were held indoors $\left(14-15^{\circ} \mathrm{C}\right.$; 12L:12D) in a 150-gallon white polypropylene tank for $42 \mathrm{~h}$ prior to starting the experiment. Following this period, eight fish were transferred to identical tanks containing clean FW (control) or artificial SW ( $32 \pm 2 \%$; Instant Ocean, Aquarium Systems, Eastlake, $\mathrm{OH}$ ). Plasma samples for sodium analysis were collected $0,8,24,48$, and $72 \mathrm{~h}$ after transfer. At Bodega Marine Laboratory (1983) , 20 fish were transferred directly from the raceways to 250 -gallon indoor circular tanks (ambient temperature; 12L:12D). Twenty fish were transferred to clean FW (control) or natural SW. During the period of study at Bodega, the daily water temperature ranged from 10 to $14^{\circ} \mathrm{C}$ and daily salinity ranged from 26 to $34 \%$ o. Plasma samples for sodium analysis were collected $24 \mathrm{~h}$ following transfer.

\section{Fluorescence microscopy}

Dimethylaminostyrylethylpyridiniumiodine (DASPEI), a vital mitochondrion-specific fluorescent stain (Bereiter-Hahn, 1976), was used to visualize and quantify mitochondrion-rich chloride cells in opercular membranes at different times during smoltification in 1982 . Opercular membranes were prepared and examined according to the method of Foskett et al. (1981). In brief, the branchial opercular membrane was freed from the operculum by gentle teasing with a blunt-tipped glass probe. The membrane, kept moist during the dissection with salmon Ringer solution $(130.0 \mathrm{mM} \mathrm{NaCl}, 5.0 \mathrm{mM} \mathrm{KCl}, 1.5 \mathrm{mM}$ $\mathrm{CaCl}_{2}, 0.8 \mathrm{mM} \mathrm{MgSO}_{4}, 1.0 \mathrm{mM} \mathrm{KH}_{2} \mathrm{PO}_{4}, 20.0 \mathrm{mM} \mathrm{NaHCO}, 1.0 \mathrm{~g} /$ glucose ), a modified Krebs-Ringer-bicarbonate solution similar to that used by Aida et al. (1980), was separated from the underlying guanine-laden connective tissue layer. The membrane was incubated in $25 \mathrm{ml}$ Ringer containing $2 \mu \mathrm{M}$ DASPEI for approximately $60 \mathrm{~min}$. Following incubation, the membrane was aligned on a glass slide with a coverslip to coincide with specific microscope stage coordinates. Utilizing a programmed Hewlett-Packard $41 \mathrm{CV}$, random areas were selected and photographed (Kodak Ectachrome 400) with a Zeiss darkfield microscope (Model RA) equipped with a fluorescent illuminator (Model II) and a BG12 exciter filter and a \#53 barrier filter. Approximately $25 \%$ of the total opercular membrane area was examined. DASPEI-fluorescent cells were counted in each photograph $\left(0.5 \mathrm{~cm}^{2}\right)$, and their densities were calculated.

\section{Electron microscopy}

Every 2 weeks, from the middle of February through May, two groups of three to five lateral gill filaments from the ventral portion of the first left gill 
arch were collected from each of five animals. Each group of gill filaments was pooled and fixed in modified Karnovsky's fixative. One group of gill filaments for scanning electron microscopy was dehydrated, dried with a Polaron (Model E-3000) critical point drier, gold palladium-coated with a Technics (Hummer, Model V) sputter coater and examined with either a Coates and Welter (Model 50) or International Scientific Instruments (Model 60) scanning electron microscope (SEM). For thin and thick sections, the second group of gill filaments was dehydrated and embedded in EPON 812 resin. Thin sections were prepared on a Porter-Blum Ultramicrotome (Model MT-II) and examined with a Siemens (Model 102) transmission electron microscope (TEM). Onemicron thick sections were similarly prepared and stained with $1 \%$ azure II and methylene blue.

Chloride cell densities were determined from thick sections. Filaments, sectioned and stained as described above, derived from three or four animals, were selected from each of four monthly sampling periods. Chloride cells were counted on 10 secondary lamellae and their corresponding interfilamentary spaces (on the primary lamella) at $100 \times$ magnification. The areas selected for examination were photographed (Kodak Plus X) with a Zeiss microscope (Model RA) equipped with a yellow filter to improve contrast. Mean chloride cell counts/cm of linear distance were calculated. Linear distance was determined from the photographs with a Numonics Corporation (Model 1224) electronic digitizer.

\section{Statistical analysis}

Student's $t$-test (assuming equal variances) was used for statistical comparisons between two groups. Statistical programs designed for the HP-41CV calculator were used for $t$-test calculations (Hewlett-Packard, Corvallis, OR) . The one-way analysis of variance together with the Student-Newman-Keuls procedure was used for statistical comparisons among multiple groups in the SW transfer experiments. Multiple comparison calculations were performed on an International Business Machine computer (Model 3081) with the Statistical Package for the Social Sciences (Release 9 of SPSS) as described by Nie et al. (1975).

\section{RESULTS}

Fig. 1 shows the changes in plasma thyroxine and gill $\mathrm{Na}^{+}, \mathrm{K}^{+}$-ATPase activity for the 1982 smolt-season. A similar pattern was observed in 1983 (Fig. 2). Thyroxine levels rose twice in both years, in February and April 1982 and in April and May 1983. In both years, gill $\mathrm{Na}^{+}, \mathrm{K}^{+}$-ATPase activity began to increase in March to an intermediate plateau level which preceded maximal activity. However, enzyme activity remained elevated through May in 1982 but 


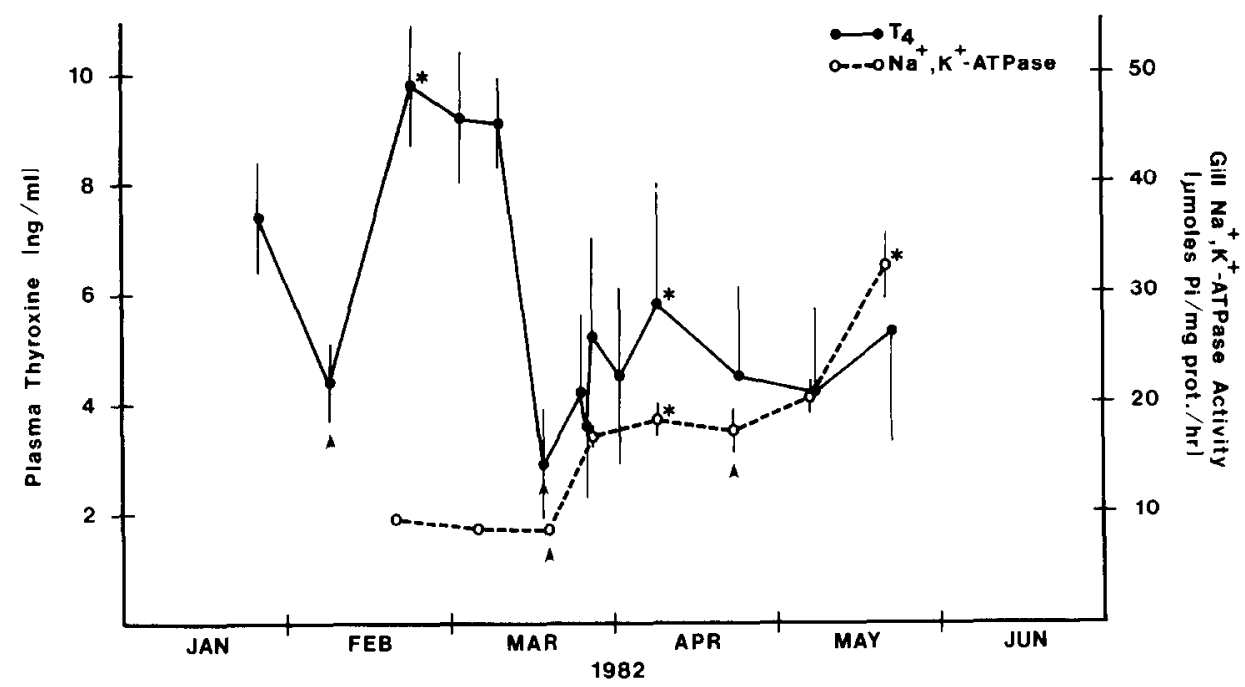

Fig. 1. Seasonal changes in plasma thyroxine titers $(O)$ and gill $\mathrm{Na}^{+}, \mathrm{K}^{+}$-ATPase activity $(\mathrm{O})$ during the smolt-season in 1982. Significant rises $(P<0.05)$ in plasma thyroxine and gill $\mathrm{Na}^{+}, \mathrm{K}^{+}$ATPase activity were determined by comparing peak levels $(*)$ with preceding low levels indicated by an arrow. Two plasma thyroxine peaks were observed, one in late February-early March and the other in April. Gill enzyme activity rose in April and in May. The initial increase in gill enzyme activity occurs at a time of increasing plasma thyroxine levels. Each point represents a mean $\pm \mathrm{SE}$ with $n=6-8$ except for $\mathrm{Na}^{\dagger}, \mathrm{K}^{+}$-ATPase on April 8, when $n=5$.

not in 1983. Plasma prolactin levels, determined only in 1983, displayed a large increase in late April (Fig. 2). Although plasma thyroxine and gill $\mathrm{Na}^{+}, \mathrm{K}^{+}-$ ATPase activity began to rise before plasma prolactin, they all displayed maximal activity late in April.

Fig. 3 shows plasma sodium levels at $0,8,24,48$ and $72 \mathrm{~h}$ after freshwater (control) and seawater transfer for seven transfer experiments during smoltification in 1982. Changes in SW tolerance may be seen by comparing representative experiments from March, April and May (Fig. 3A). In March (line 1), plasma sodium levels in animals $24 \mathrm{~h}$ after transfer to $\mathrm{SW}$ were significantly higher $(P<0.05)$ than those in later experiments. During late March and early April (lines 3,4 and 5) plasma sodium levels in SW-transferred animals were not significantly different from each other and were nearly constant after $8 \mathrm{~h}$. Plasma sodium levels from SW-transferred animals in late May (line 7 ), while similar at $0,8,12$ and $24 \mathrm{~h}$ were significantly lower $(P<0.05)$ at $48 \mathrm{~h}$ compared with what was seen in previous experiments.

Plasma sodium levels from animals transferred from $\mathrm{FW}$ to $\mathrm{FW}$ (controls) were variable with some significant differences (Fig. 3B). The most notably different were the levels from animals transferred in late May (line 7) which were significantly lower $(P<0.05)$ than those in early April (line 4$)$ at $48 \mathrm{~h}$. This difference may be reflected in the FW- to SW-transferred animals also 


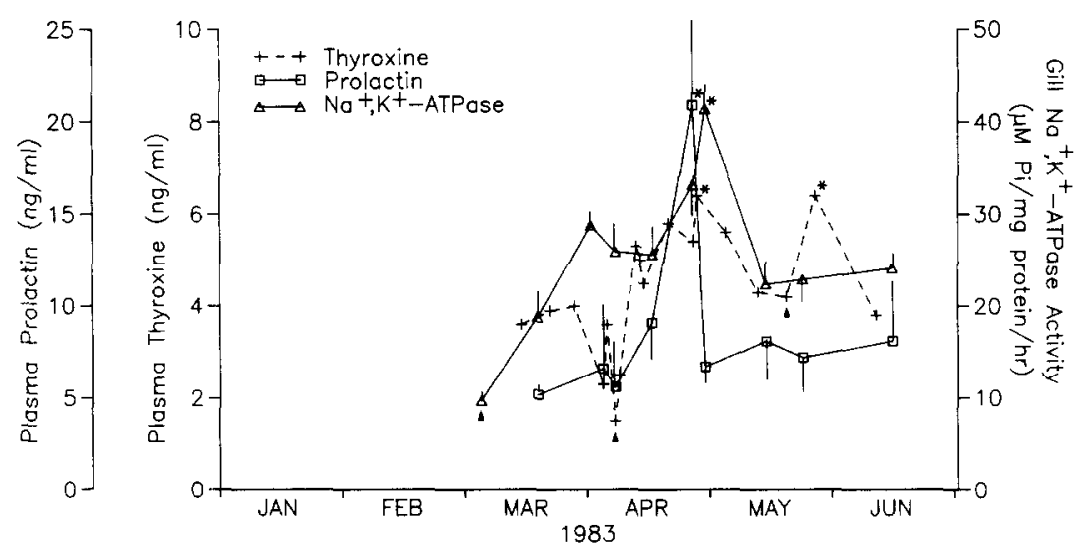

Fig. 2. Seasonal changes in plasma thyroxine $(+)$ and prolactin $(\square)$ levels, and gill $\mathrm{Na}^{+}, \mathrm{K}^{+}-$ ATPase activity $(\Delta)$ during smoltification in 1983. Significant rises $(P<0.05)$ in plasma thyroxine and gill $\mathrm{Na}^{+}, \mathrm{K}^{+}$-ATPase activity were determined by comparing peak levels $(*)$ with preceding low levels indicated by an arrow. A significant increase $(P<0.01)$ in plasma prolactin levels was observed during the month of April compared with the levels in March. Peak plasma prolactin levels coincide with peak levels of plasma thyroxine and gill $\mathrm{Na}^{+}, \mathrm{K}^{+}$-ATPase activity. Thyroxine data for 1983 are the same as those published by Nishioka et al. (1985). Each point represents mean $\pm \mathrm{SE}$ with $n=6-8$. The $\mathrm{SE}_{\mathrm{m}}$ have been omitted from the thyroxine data for clarity.

(line 7, Fig. 3A). However, in late April (line 5) a similar drop in plasma sodium levels was observed in FW-transferred but not in SW-transferred animals.

DASPEI-positive cell density in opercular membranes, a putative model of the branchial epithelium, was constant in March, April, and early May 1982 (Table 1). The density remained constant during this period despite an increase in gill $\mathrm{Na}^{+}, \mathrm{K}^{+}$-ATPase activity (Fig. 1) and SW tolerance (Fig. 3A). However, in late May the number of cells increased two-fold which was coincident with the second increase in gill $\mathrm{Na}^{+}, \mathrm{K}^{+}$-ATPase activity and in SW tolerance.

In light of the $1982 \mathrm{SW}$-transfer experiments, SW tolerance in 1983 was evaluated from periodic $24-\mathrm{h} \mathrm{SW}$-transfer experiments. Plasma sodium levels in SW-transferred animals were similar and nearly constant during most of smoltification (Fig. 4). However, in late May, the levels were significantly greater $(P<0.05)$ than those observed earlier. This increase occurred at a time of reduced gill $\mathrm{Na}^{+}, \mathrm{K}^{+}$-ATPase activity.

In contrast to chloride cells in the opercular membrane (1982), gill filament chloride cell density (1983) remained constant in both primary and secondary lamellae (Table 1 ) despite the increase in gill $\mathrm{Na}^{+}, \mathrm{K}^{+}$-ATPase activity (Fig. 1). However, in the SEM study the surface of secondary lamellae appeafed to change during this period. In early March, the surface appeared rough and infolded (Fig. 5a). As smoltification progressed, the surface became smoother than observed earlier (Fig. $5 b$ and c) and, although not shown, the secondary 

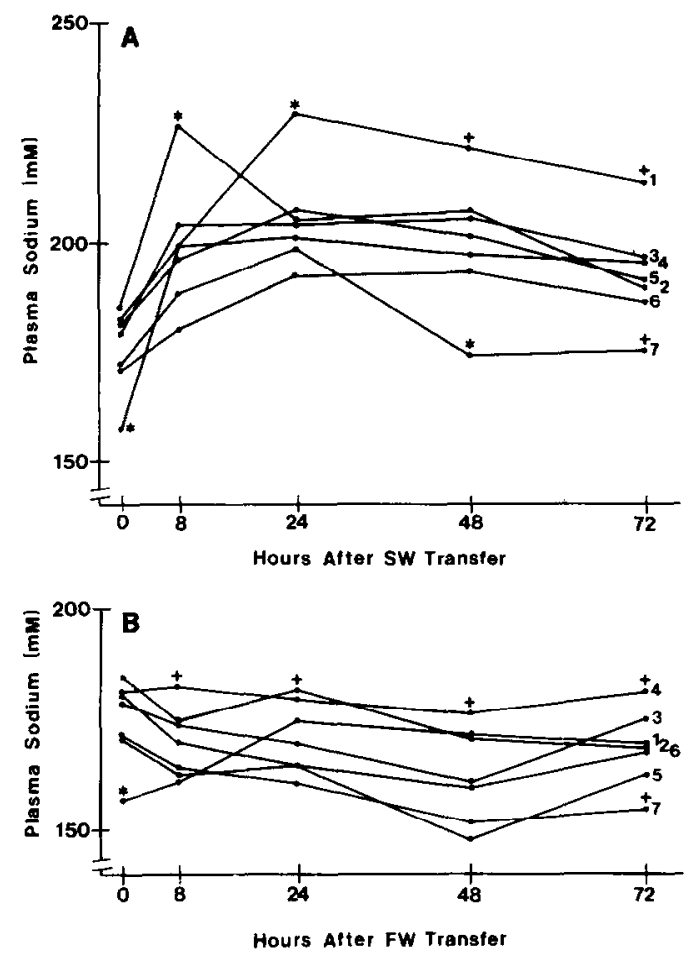

Fig. 3. Mean plasma sodium levels at $0,8,24,48$, and $72 \mathrm{~h}$ after seawater (A) or freshwater (B) transfer for seven separate transfer experiments in 1982. The numbers following each line indicate the chronological order of the experiments and correspond to the following dates: (1) 8 March; (2) 20 March; (3) 28 March; (4) 9 April; (5) 24 April; (6) 8 May; (7) 22 May. *Significantly different $(P<0.05)$ compared with other mean values in the same sampling period. + Represents a group of mean values which are significantly different $(P<0.05)$. In SW they are: line 1 at $48 \mathrm{~h}$ is different from lines 4 and 6 ; line 1 at $72 \mathrm{~h}$ is different from lines $2,5,6$, and 7 ; line 7 at $72 \mathrm{~h}$ is different from line 1 . Similar comparisons made on the FW-transferred animals also revealed some group differences. They are: line 4 at $8 \mathrm{~h}$ is different from line 1 ; line 2 at $24 \mathrm{~h}$ is different from line 7; lines 1 and 4 at $48 \mathrm{~h}$ are different from lines 5 and 7 ; line 7 at $72 \mathrm{~h}$ is different from lines 3 and 4 ; line 4 at $72 \mathrm{~h}$ is different from lines 5 and 7 . Comparisons among lines 1,4 and 7 in SW animals show an increase in SW tolerance during smoltification (see text for discussion). Each point represents a mean with $n=6-8$, except in line 4 at $8 \mathrm{~h}$, when $n=5$. Standard error bars have been omitted for clarity.

lamellae appeared thinner in some cases. Toward the end of smoltification (May) the secondary lamellae once again became rough (Fig. 5d) and in one animal appeared similar to what was observed initially.

Two types of mitochondrion-rich (chloride) cells were observed with TEM. Early in the study (February), cells contained either large, circular mitochondria (type I cells) or thin, elongate mitochondria (type II cells) (Figs. 6a,b). Type I cells had less electron-dense cytoplasm and fewer mitochondria than type II cells (Fig. 6) and, in some instances, were in a state of cellular disrup- 

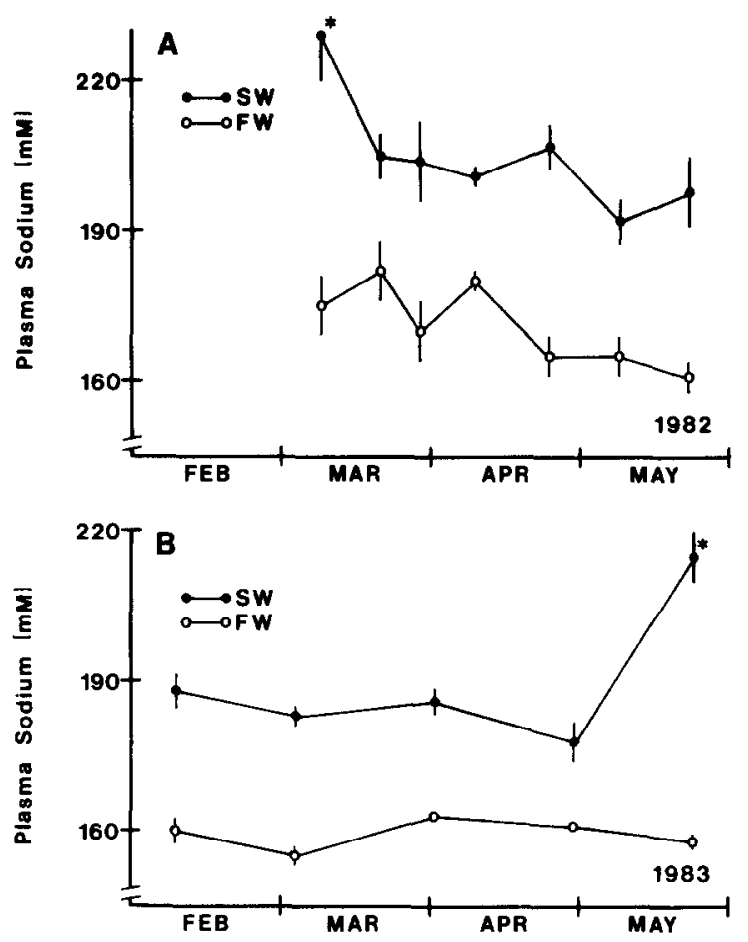

Fig. 4. Seasonal variation in plasma sodium levels in FW (O) and after $24 \mathrm{~h}$ in SW (O) during 1982 (A) and 1983 (B) smoltification, respectively. In 1983, at this time point, only the initial change in SW tolerance is observed. In 1983 an enhanced SW tolerance is not apparent. The large change in plasma sodium levels in SW animals between late April and May indicates a decline of SW tolerance and marks the end of smoltification. *Significantly different $(P<0.05)$ from other 24-h SW-transfer experiments. Each point represents a mean. The vertical bar is the SE with $n=6-8$.

\section{TABLE 1}

Seasonal changes in chloride cell density in coho opercular membranes and gill lamellae during smoltification

\begin{tabular}{lcll}
\hline Month & $\begin{array}{l}\text { Opercular } \\
\text { membranes } \\
(\text { cells/cm }\end{array}$ & Gill lamellae & \\
\cline { 3 - 4 } & - & $\begin{array}{l}\text { Primary } \\
\text { (cells/cm) }\end{array}$ & $\begin{array}{l}\text { Secondary } \\
\text { (cells/cm) }\end{array}$ \\
\hline Feb. & $677 \pm 219(4)$ & $585 \pm 47(5)^{a}$ & $49 \pm 12$ \\
Mar. & $682 \pm 189(7)$ & $402 \pm 60(5)$ & $45 \pm 9$ \\
Apr. & $663 \pm 260(4)$ & $526 \pm 62(6)$ & $44 \pm 10$ \\
May (early) & $1533 \pm 275(8)^{*}$ & $441 \pm 75(6)$ & $53 \pm 5$ \\
May (late) & - & - \\
\hline
\end{tabular}

${ }^{a}$ Mean $\pm \mathrm{SE}$ with $n$ in parentheses. $N$ for gill filaments examined represent three to four animals and are the same for both lamellae. For opercular membranes, each membrane represents one animal.

*Significantly different $(P<0.05)$ compared with April. 

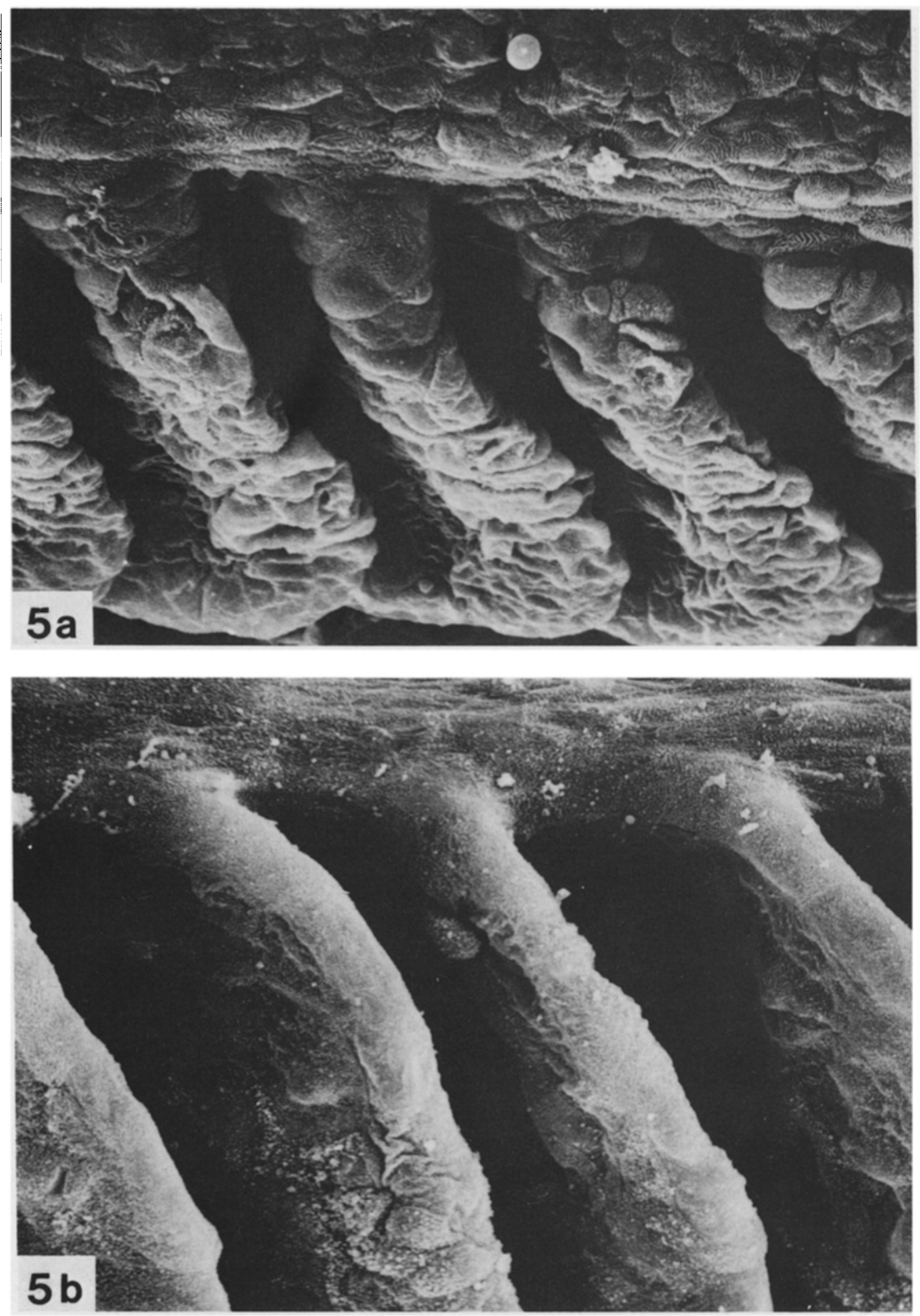

Fig. 5. SEM photomicrographs $(970 \times)$ of primary and secondary lamellae in early March (a), late March (b), early April (c), and May (d). Note the rough surface in early March (a), the transition to a smooth surface during smoltification (b), and the reappearance of a rough surface (c and d). 

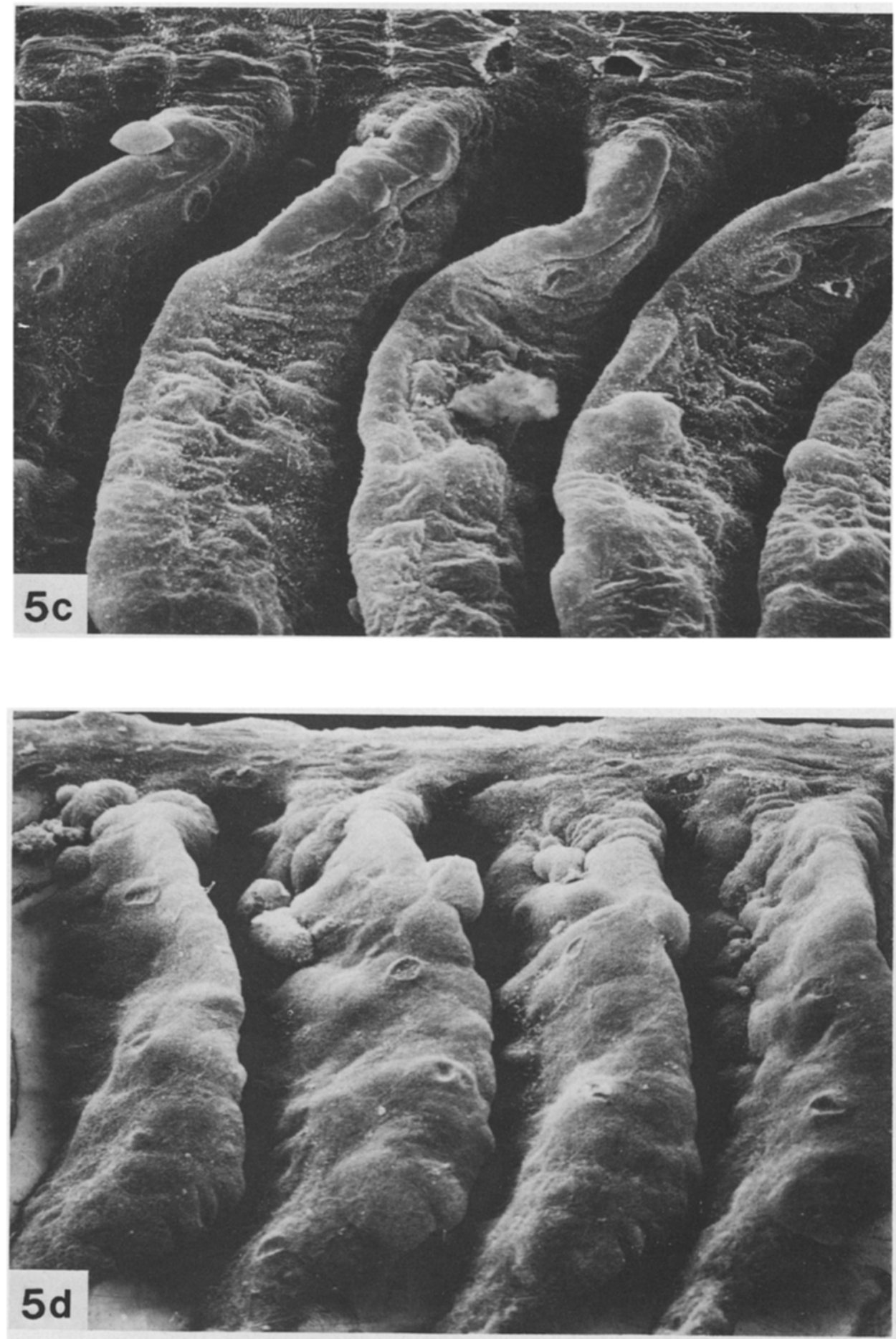

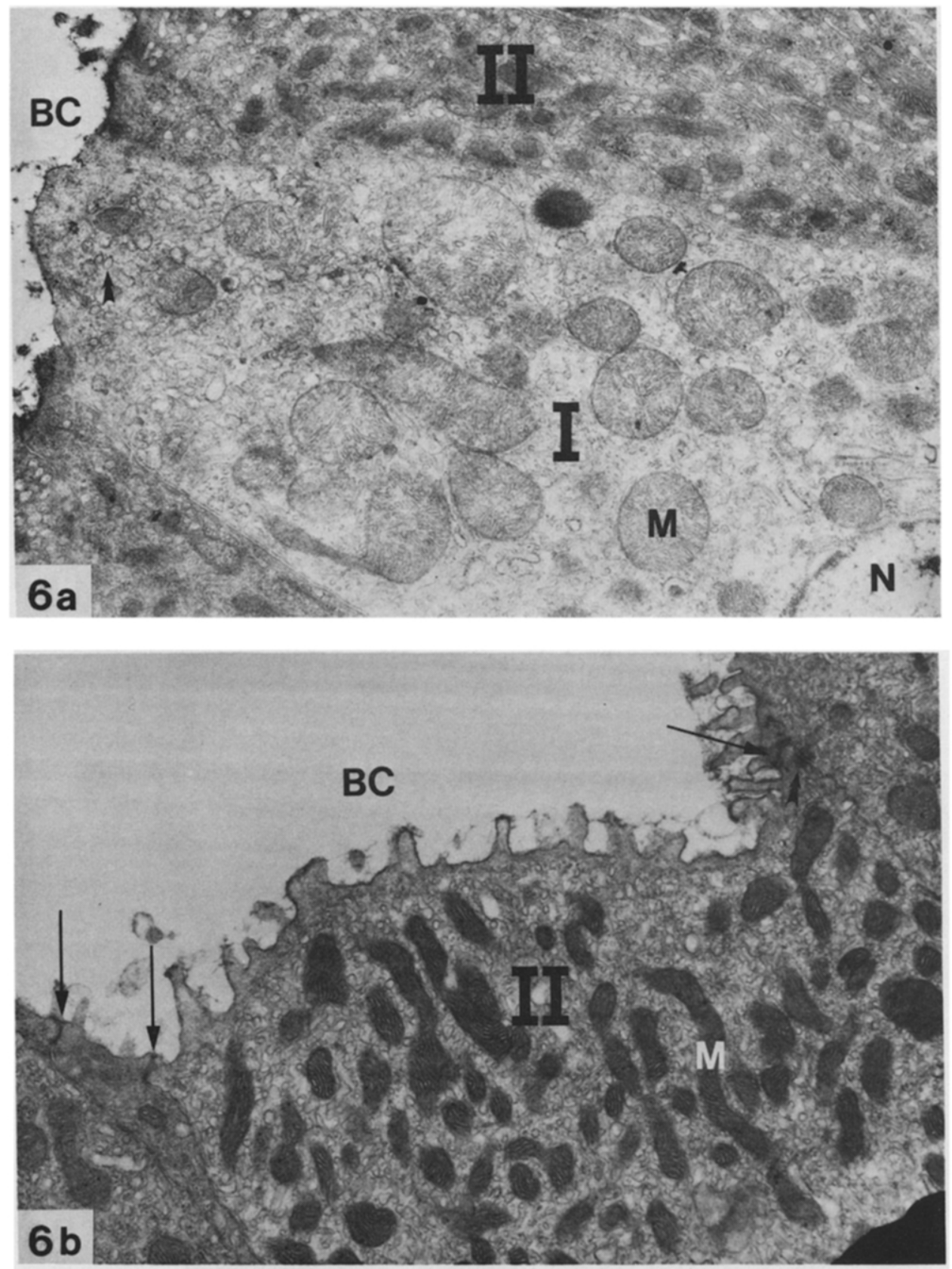

Fig. 6. Type I (a) and type II (b) mitochondrion-rich (chloride) cells (12 600X) are illustrated from February and April, respectively. Type I cells contain large circular mitochondria and have a less electron-dense cytoplasm than type II cells. Type II cell mitochondria are elongated and more electron-dense than those found in type I cells. The short arrow in (a) marks structures which may represent either microvesicles or the tubular system in cross-section. Note the extensive tubular system and the tight junctions (long arrows) and desmosome (short arrow) between cells in (b). Abbreviations are: I, type I cell; II, type II cell; N, nucleus; M, mitochondrion; BC, branchial cavity. 


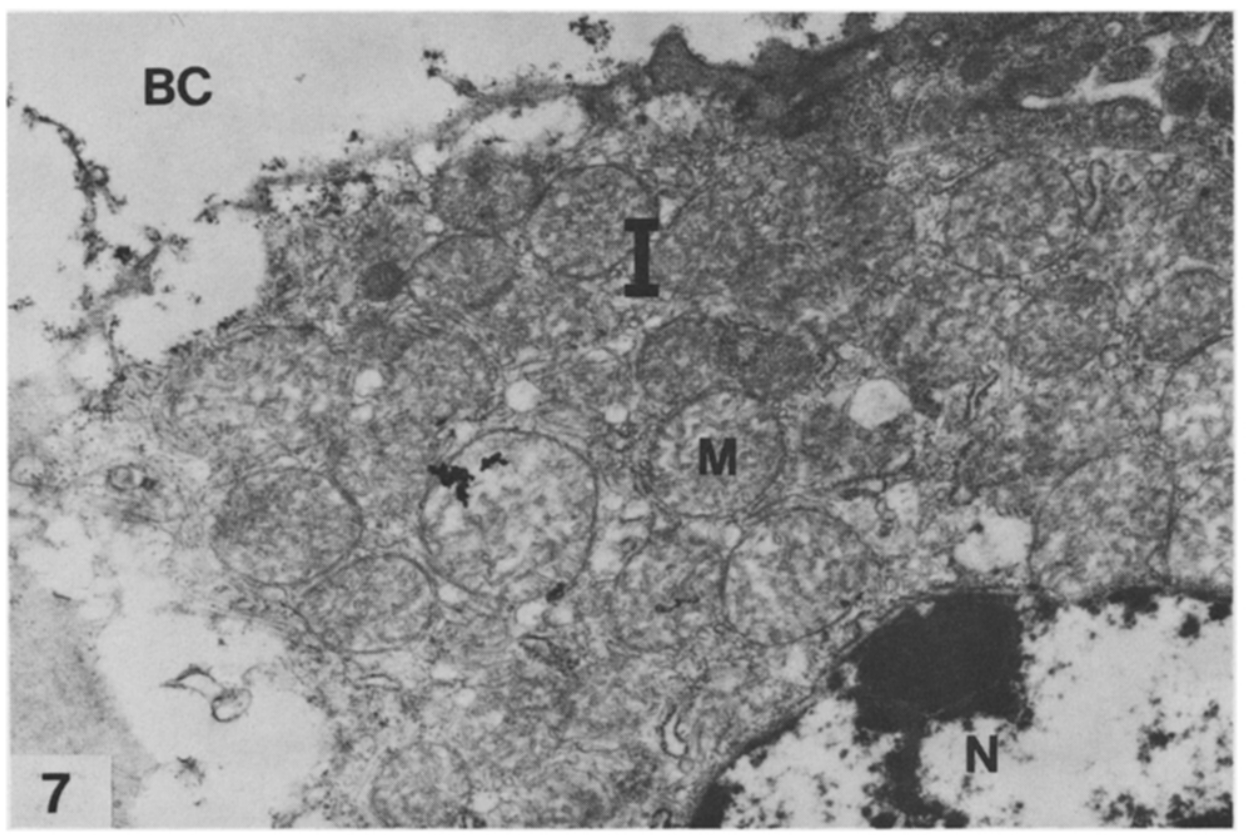

Fig. 7. TEM photomicrograph $(15350 \times)$ of a mitochondrion-rich type I cell in a state of cellular disruption. Disrupted type I cells have been observed on both primary and secondary lamellae. Abbreviations are: I, type I cell; N, nucleus; M, mitochondrion; BC, branchial cavity.

tion (Fig. 7). Throughout most of the study, the apical surfaces of both cell types were aligned with those of the adjacent epithelial cells. However, in the final sampling period ( 28 May), the surface of some secondary lamellae appeared infolded or rugose. In these lamellae, apical surfaces of the type II cell (type I cells were not observed) were below those of the neighboring epithelial cells (Fig. 8). Although not illustrated, the apical surface of either cell type may be partially covered, to a variable degree, by narrow extensions from surrounding epithelial cells. Apical surface microvilli, when present, appeared to be more extensive on type II cells. The junctions between cells appeared to be tight junctions (zonulae occludentes); desmosomes were also observed (arrows, Fig. 6b).

\section{DISCUSSION}

Seawater tolerance increased during the 1982 smolt-season. The SW transfer experiments showed two discrete changes in plasma sodium levels, the first in early March and the second in late May. Although more closely associated with the May increase in SW tolerance, gill $\mathrm{Na}^{+}, \mathrm{K}^{+}$-ATPase activity rose during both periods of changing SW tolerance. In agreement with the 'SW Chal- 


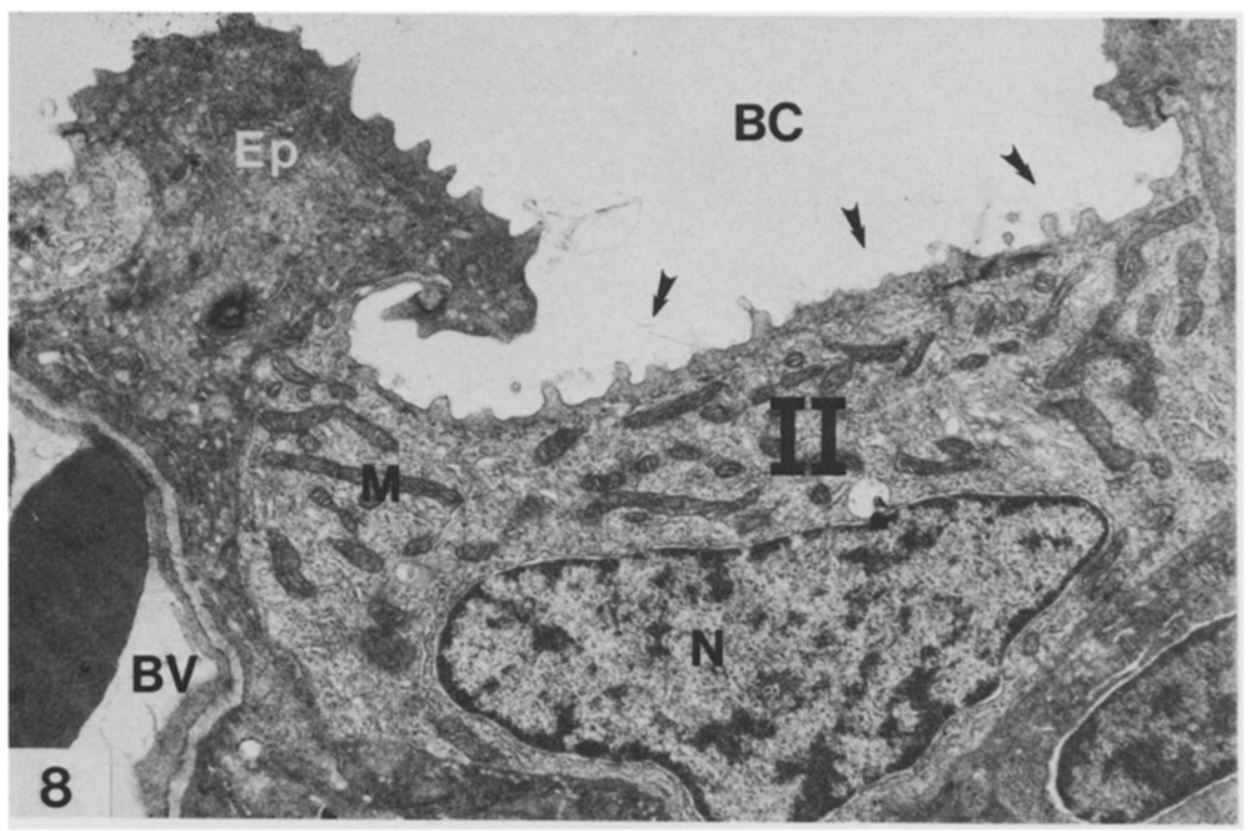

Fig. 8. Type II cell $(7550 \times)$ on a secondary lamella from a rugose gill filament. Some secondary lamellar surfaces observed in the final sampling period were rugose in appearance. Type II cells in these lamellae have apical surfaces which form shallow cavities (arrows). Type I cells were not observed. Abbreviations are: II, type II cell; N, nucleus; M, mitochondrion; BC, branchial cavity; Ep, epithelial cell; BV, blood vessel.

lenge Test' of Clarke and Blackburn (1977), these data suggest that a single sampling at either 24 or $48 \mathrm{~h}$ after SW transfer is sufficient to evaluate SW tolerance in coho. The reason for the failure to detect an improvement in SW tolerance in 1983 is unclear. The response may, in part, be due to the somewhat lower salinity levels of the natural SW. Alternatively, maximal gill $\mathrm{Na}^{+}, \mathrm{K}^{+}$ATPase activity appeared earlier in 1983 and a decline in SW tolerance was observed in 1983 but not in 1982. These differences would indicate that smoltification occurred earlier in 1983; thus, changes in SW tolerance may have occurred prior to our initial sampling in 1983.

Although multiple peaks in plasma thyroxine have been described in coho salmon (Grau et al., 1981, 1985), most studies have shown only a single peak during smoltification (Dickhoff et al., 1978; Folmar and Dickhoff, 1981; Grau et al., 1981; Boeuf and Prunet, 1985; Yamauchi et al., 1985). In this study, two thyroxine peaks were observed in both years. The February peak in 1982 was greater than the April peak of that year and greater than either peak in 1983. In 1982, two relationships between plasma thyroxine titers and osmoregulatory performance after $\mathrm{SW}$ transfer were evident. First, the 24 - and 48 -h declines 
in SW plasma sodium levels were preceded by increases in plasma thyroxine titers and were coincident with increases in gill $\mathrm{Na}^{+}, \mathrm{K}^{+}$-ATPase activity. Second, the initial increase in SW tolerance and in gill $\mathrm{Na}^{+}, \mathrm{K}^{+}$-ATPase activity was preceded by the February thyroxine peak and was coincident with the April thyroxine peak. The latter is similar to what occurred in 1983 when gill enzyme levels and plasma thyroxine titers rose concurrently. Both patterns are in agreement with the findings of Folmar and Dickhoff (1981) that longterm SW survival and growth increased in relation to the portion of the thyroxine peak which occurred prior to SW entry. Although these relationships suggest an effect of thyroid hormones in the development of seawater tolerance, they may represent independent events which are similarly timed to meet the total developmental needs of the animals.

Plasma prolactin levels rose four-fold in April (1983), concurrent with elevated plasma thyroxine and gill $\mathrm{Na}^{+}, \mathrm{K}^{+}$-ATPase activity. The role of prolactin in smoltification remains to be elucidated. Prolactin, the putative FWadapting hormone in euryhaline fishes (Loretz and Bern, 1982), may act to maintain FW homeostasis in the face of changing chloride cell activity and/or it could play a role in development analogous with its action in the metamorphosis of many amphibians ( for review, see White and Nicoll, 1981). Although not observed in all studies, the decline in plasma electrolyte levels found by some investigators in FW-adapted salmon during smoltification is consistent with changing chloride cell activity (Houston and Threadgold, 1963; Folmar and Dickhoff, 1981). In this context, the possible interaction between prolactin and osmoregulatory organs (i.e., gills, opercular membranes, skin, gastrointestinal tract, kidney, and urinary bladder) during smoltification deserves more consideration.

Chloride cells, known to excrete ions in SW (Foskett and Scheffey, 1982), are, in part, responsible for regulating plasma ions. Chloride cell-containing flat epithelia (such as opercular membrane and skin) have been used in electrophysiological studies as models for gill chloride cell function (e.g., Karnaky and Kinter, 1977; Marshall and Nishioka, 1980; Foskett et al., 1983; Karnaky, 1986). As a model, the coho opercular membrane may be expected to reflect changes in gill chloride cells. The density of chloride cells found in coho opercular epithelium is low compared with that seen in other euryhaline species (e.g., Foskett et al., 1983). DASPEI-positive cell density remained constant until early May after which it increased two-fold. Although gill $\mathrm{Na}^{+}, \mathrm{K}^{+}$ATPase activity rose first in March, a second rise in enzyme activity was coincident with the increase in cell density. This relationship suggests that improved SW tolerance during the 1982 smolt-season resulted from an initial increase in enzyme activity per cell and, later, an increase in chloride cell density.

In this study, two morphologically distinct chloride cell types were found in the gill epithelium: type I contained large, circular mitochondria and type II contained thin, elongate mitochondria. In addition, type II cells were more 
electron dense. Many type I cells were found in a state of cellular disruption which may represent specific degeneration or an artifact of fixation wherein type I cells may be more sensitive to the fixation process. Although our results are unable to identify the nature of type I cell disruption, observations of intact or disrupted type I cells in TEM were infrequent in the latter half of the smoltseason. However, the total number of chloride cells (type I plus type II) did not change during this period. Type I and type II cell densities may have changed independently, but the inability to distinguish between these cell types with the light microscope prevented their quantification.

Smoltification-associated changes in gill morphology have been reported for other salmonid species. Threadgold and Houston (1964) described cellular disruption of gill chloride cells in Atlantic salmon parr similar to that observed in this study. Steelhead trout (Salmo gairdneri) held in FW exhibited two peaks in chloride cell density in primary and secondary gill lamellae: one for both lamellae in May, the normal migratory period, and the other in August for primary lamellae and in November for secondary lamellae (Wickes et al., 1983). Langdon and Thorpe (1984a) found that the abundance of FW chloride cells, defined as cells having low $\mathrm{Na}^{+}, \mathrm{K}^{+}$-ATPase and succinate dehydrogenase activity, decreased during smoltification in Atlantic salmon.

Although gill $\mathrm{Na}^{+}, \mathrm{K}^{+}$-ATPase activity is located primarily in chloride cells (Langdon and Thorpe, 1984a), changes in gill enzyme activity and chloride cell density are not necessarily concurrent events. In this study, enzyme activity increased with and without changes in opercular membrane chloride cell density. In a similar study (Loretz et al., 1982), we found an increase in coho opercular chloride cell density which was gradual and closely associated with rising gill enzyme activity. Langdon and Thorpe (1984b) observed a modest rise in yield of chloride cells from dissociated gill epithelium in second-year Atlantic salmon smolts which corresponded with elevated gill $\mathrm{Na}^{+}, \mathrm{K}^{+}$-ATPase and succinate dehydrogenase activity. In contrast, the rise in chloride cell yield in first-year smolts occurred earlier and before an increase in gill $\mathrm{Na}^{+}, \mathrm{K}^{+}$. ATPase activity.

The morphology of chloride cells has been described as FW or SW in nature based on their appearance in fish adapted to these environments. Type I cells are electron-lucent and contain circular mitochondria compared with type II cells. Similarly, chloride cells from FW-adapted Fundulus heteroclitus (Kessel and Beams, 1962) and Anguilla rostrata (Doyle and Epstein, 1972) have been shown to be less electron-dense than their SW counterparts. Moreover, Kessel and Beams (1962) reported that the mitochondria in chloride cells in FWadapted $F$. heteroclitus appear thicker and shorter than those from $\mathrm{SW}$-adapted animals. In SW-adapted animals, only the electron-dense chloride cells form the characteristic apical pit (Doyle and Gorecki, 1961; Kessel and Beams, 1962; Doyle and Epstein, 1972). The apical cavity observed in type II cells in late May is reminiscent of apical pits formed by chloride cells in SW (cf. Philpott 
and Copeland, 1963; Laurent and Dunel, 1980; Foskett et al., 1983; Karnaky, 1986 ). Together, these similarities suggest that the type I cell may represent a "FW-chloride cell" and the type II cell may represent a "SW-chloride cell". However, type II cell apical cavities were not present in all animals and, when present, occurred in late May, a time of reduced gill $\mathrm{Na}^{+}, \mathrm{K}^{+}$-ATPase activity and SW tolerance.

It is unclear whether the morphological differences ascribed to chloride cells in different environments represent two distinct cell types or a single cell type with morphology dependent upon the direction of ion movement (see Pisam, 1981). Although type I and type II cells may represent a single cell type, a distinct intermediate cell series between them was not observed. However, prior to the formation of an apical cavity in the type II cells, the apical surfaces of both cell types were aligned with the apical surface of neighboring cells, a characteristic often found in FW-chloride cells (Doyle and Gorecki, 1961; Philpott and Copeland, 1963; Shirai and Utida, 1970; Doyle and Epstein, 1972; Hossler, 1980 ). In the Japanese eel (A. japonica), Shirai and Utida (1970) found that upon entrance into SW both "type A" and "type B" chloride cells formed apical pits with the subsequent development of additional "type A" cells from "type B" cells. In the mullet (Mugil cephalus) and $F$. heteroclitus, temporal changes in apical membrane invagination or protrusion were observed with SEM during adaptation to saline or FW environments, respectively (Hossler, 1980; Hossler et al., 1985). While these observations support the notion of a single pleomorphic chloride cell type, tritiated thymidine studies with two species of salmon, $O$. kisutch and $O$. tshawytscha, have shown that gill DNA turnover is greater in SW-adapted animals (Conte and Lin, 1967).

Recent studies have shown that gill chloride cells in several SW-adapted euryhaline species as well as in the stenohaline SW Solea solea form multicellular complexes with one or more smaller chloride cells whose fingerlike projections interdigitate with the larger cell in the apical region (Sardet et al., 1979; Hootman and Philpott, 1980; Laurent and Dunel, 1980; Dunel-Erb and Laurent, 1980; Sardet, 1980). In contrast, these multicellular complexes were not found in FW-adapted animals with the exception of Fundulus heteroclitus. Freshwater Fundulus retained multiple chloride cell complexes; however, the shallow tight junctions normally observed between chloride cells in SW were replaced with deep (ca. $600 \mathrm{~nm}$ ) tight junctions (Karnaky, 1986). Thus, SW adaptation in some euryhaline teleosts appears to be associated with the development of additional mitochondrion-rich cells which form multicellular complexes with preexisting individual chloride cells. Although these cells have a general morphology consistent with that expected for a developing chloride cell, in the pinfish Hootman and Philpott (1980) describe these smaller cells as accessory cells, noting ultrastructural differences in electron density, mitochondrial shape, and diameter of the basolateral tubular system. Moreover, the tubular system in these cells, unlike that of chloride cells, does not react 
histochemically for $\mathrm{Na}^{+}, \mathrm{K}^{+}$-ATPase. Interestingly, the mitochondrial morphology in type I cells is similar to that in accessory cells. However, accessory cell cytoplasm and mitochondria were more electron-dense than in type I cells. In addition, neither type I nor type II cells were observed interdigitating with other type I or type II cells.

The surface of secondary lamellae as observed by SEM appeared to change during the 1982 smolt-season. The transition from a rough to a smooth surface may reflect changes in the epithelium or in the subepithelial space of the secondary lamellae. In A. australis, this space became enlarged from edema during in vitro perfusion of isolated holobranchs. In edematous filaments, the secondary lamellae appeared by SEM to be enlarged and smooth (Ellis and Smith, 1983). Although occurrence of edema was not specifically examined in this study, expanded subepithelial spaces were noted in some secondary lamellae. Enlargement of the subepithelial space may represent edema or, alternatively, a change in gill sensitivity to the fixation process during smoltification.

The morphological observations on gills and opercular membranes and their relationship to gill $\mathrm{Na}^{+}, \mathrm{K}^{+}$-ATPase activity and $\mathrm{SW}$ tolerance suggest that chloride cell proliferation and/or differentiation occurs during smoltification. Although fixation effects cannot presently be excluded, the occurrence of specific chloride cell disruption both in Atlantic salmon parr (Threadgold and Houston, 1964) and in coho parr of this study may indicate specific degeneration of type I cells. The failure to detect significant differences in gill chloride cell density may be the result of either too few sampling periods or an overlapping of chloride cell degeneration with replacement. The observed changes in gill surface morphology, a rough surface which became smoother during smoltification and then rough again toward the end of smoltification, are in agreement with a smoltification-associated alteration of gill epithelium. This process may represent the loss of FW-chloride cells and/or their replacement with SWchloride cells.

\section{ACKNOWLEDGMENTS}

We are grateful to Dr. Waldo Zaugg for the $\mathrm{Na}^{+}, \mathrm{K}^{+}$-ATPase analysis of the gill tissue and to Dr. Terry Machen for his astute criticism of the manuscript. We wish to thank John Underhill, Phyllis Thompson, Richard Lin, Rodolfo Rivas, and Karen Mills for their help in the technical preparation of the manuscript. We also wish to express our appreciation to the California Department of Fish and Game for their kind cooperation. This work is a result of research sponsored in part by NOAA, National Sea Grant College Program, Department of Commerce, under grant number NOAA NA80AA-D-00120, Project number R/F-78, through the California Sea Grant College Program, and in part by the California State Resources Agency and by NSF grant PCM 84- 
05249 to H.A. Bern and by a NATO grant to P. Prunet. The U.S. Government is authorized to reproduce and distribute for governmental purposes.

\section{REFERENCES}

Aida, K., Nishioka, R.S. and Bern, H.A., 1980. Degranulation of the Stannius corpuscles of coho salmon (Oncorhynchus kisutch) in response to ionic changes in vitro. Gen. Comp. Endocrinol., 41: 305-313.

Barron, M.G., 1986. Endocrine control of smoltification in anadromous salmonids. J. Endocrinol., 108: 313-319.

Bereiter-Hahn, J., 1976. Dimethylaminostyrylmethylpyridiniumiodine (DASPMI) as a fluorescent probe for mitochondria in situ. Biochim. Biophys. Acta, 423: 1-14.

Boeuf, G. and Prunet, P. 1985. Measurements of gill $\left(\mathrm{Na}^{+}-\mathrm{K}^{+}\right)$-ATPase activity and plasma thyroid hormones during smoltification in Atlantic salmon (Salmo salar L.) . Aquaculture, 45: 111-119.

Chernitsky, A.G., 1980. Functional state of chloride cells of Baltic salmon (Salmo salar L.) at different stages of its life cycle. Comp. Biochem. Physiol. A, 67: 519-522.

Clarke, W.C. and Blackburn, J., 1977. A seawater challenge test to measure smolting of juvenile salmon. Fish. Mar. Serv. Res. Div. Tech. Rep. 705, 11 pp.

Conte, F.P. and Lin, D.H.Y., 1967. Kinetics of cellular morphogenesis in gill epithelium during sea water adaptation of Oncorhynchus (Walbaum). Comp. Biochem. Physiol., 23: 945-957.

Dickhoff, W.W., Folmar, L.C. and Gorbman, A., 1978. Changes in plasma thyroxine during smoltification of coho salmon, Oncorhynchus kisutch. Gen. Comp. Endocrinol., 36: 229-232.

Doyle, W.L. and Epstein, F.H., 1972. Effects of cortisol treatment and osmotic adaptation on the chloride cells in the eel, Anguilla rostrata. Cytobiologie Z. Exp. Zellforsch., 6: 58-73.

Doyle, W.L. and Gorecki, D., 1961. The so-called chloride cell of the fish gill. Physiol. Zool., 34: 81-85.

Dunel-Erb, S. and Laurent, P., 1980. Ultrastructure of marine teleost gill epithelia: SEM and TEM study of the chloride cell apical membrane. J. Morphol., 165: 175-186.

Ellis, A.G. and Smith, D.G., 1983. Edema formation and impaired $\mathrm{O}_{2}$ transfer in Ringer-perfused gill of the eel, Anguilla australis. J. Exp. Zool., 227: 371-380.

Folmar, L.C. and Dickhoff, W.W., 1980. The parr-smolt transformation (smoltification) and seawater adaptation in salmonids. A review of selected literature. Aquaculture, 21: 1-37.

Folmar, L.C. and Dickhoff, W.W., 1981. Evaluation of some physiological parameters as predictive indices of smoltification. Aquaculture, 23: 309-324.

Foskett, J.K. and Scheffey, C., 1982. The chloride cell: definitive identification as the salt-secretory cell in teleosts. Science, 215: 164-166.

Foskett, J.K., Logsdon, C.D., Turner, T., Machen, T.E. and Bern, H.A., 1981. Differentiation of the chloride extrusion mechanism during seawater adaptation of a teleost fish, the cichlid Sarotherodon mossambicus. J. Exp. Biol., 93: 209-224.

Foskett, J.K., Bern, H.A., Machen, T.E. and Conner, M., 1983. Chloride cells and the hormonal control of teleost fish osmoregulation. J. Exp. Biol., 106: 255-281.

Grau, E.G., Dickhoff, W.W., Nishioka, R.S., Bern, H.A. and Folmar, L.C., 1981. Lunar phasing of the thyroxine surge preparatory to seaward migration of salmonid fish. Science, 211:607-609.

Grau, E.G., Fast, A.W., Nishioka, R.S., Bern, H.A., Barclay, D.K. and Katase, S.A., 1985. Variations in thyroid hormone levels and in performance in the seawater challenge test accompanying development in coho salmon raised in Hawaii. Aquaculture, 45: 121-132.

Hirano, T., Prunet, P., Kawauchi, H., Takahashi, A., Ogasawara, T., Kubota, J., Nishioka, R.S., 
Bern, H.A., Takada, K. and Ishii, S., 1985. Development and validation of a salmon prolactin radioimmunoassay. Gen. Comp. Endocrinol., 59: 266-276.

Hoar, W.S., 1976. Smolt transformation: evolution, behavior, and physiology. J. Fish. Res. Board Can., 33: 1234-1252.

Hootman, S.R. and Philpott, C.W., 1980. Accessory cells in teleost branchial epithelium. Am. J. Physiol., 238: R199-R206.

Hossler, F.E., 1980. Gill arch of the mullet, Mugil cephalus. III. Rate of response to salinity change. Am. J. Physiol., 238: R160-R164.

Hossler, F.E., Musil, G., Karnaky, K.J., Jr. and Epstein, F.H., 1985. Surface ultrastructure of the gill arch of the killifish, Fundulus heteroclitus, from seawater and freshwater, with special reference to the morphology of apical crypts of chloride cells. J. Morphol., 185: 377-386.

Houston, A.H. and Threadgold, L.T., 1963. Body fluid regulation in smolting Atlantic salmon. J. Fish. Res. Board Can., 20: 1355-1369.

Karnaky, K.J., Jr., 1986. Structure and function of the chloride cell of Fundulus heteroclitus and other teleosts. Am. Zool., 26: 209-224.

Karnaky, K.J., Jr. and Kinter, W.B., 1977. Killifish opercular skin: a flat epithelium with a high density of chloride cells. J. Exp. Zool., 199: 355-364.

Kessel, R.G. and Beams, H.W., 1962. Electron microscope studies on the gill filaments of Fundulus heteroclitus from sea water and fresh water with special reference to the ultrastructural organization of the "chloride cell". J. Ultrastruct. Res., 6: 77-87.

Langdon, J.S. and Thorpe, J.E., 1984a. Response of the gill $\mathrm{Na}^{+}-\mathrm{K}^{+}$ATPase activity, succinic dehydrogenase activity and chloride cells to saltwater adaptation in Atlantic salmon, Salmo salar L., parr and smolt. J. Fish Biol., 24: 323-331.

Langdon, J.S. and Thorpe, J.E., 1984b. The ontogeny of smoltification: developmental patterns of gill $\mathrm{Na}^{+} / \mathrm{K}^{+}$-ATPase, SDH, and chloride cells in juvenile Atlantic salmon, Salmo salar $\mathrm{L}$. Aquaculture, 45: 83-95.

Laurent, P. and Dunel, S., 1980. Morphology of gill epithelia in fish. Am. J. Physiol., 238: R147-R159.

Loretz, C.A. and Bern, H.A., 1982. Prolactin and osmoregulation in vertebrates. Neuroendocrinology, 35: 292-304.

Loretz, C.A., Collie, N.L., Richman, N.H., III and Bern, H.A., 1982. Osmoregulatory changes accompanying smoltification in coho salmon. Aquaculture, 28: 67-74.

Marshall, W.S. and Nishioka, R.S., 1980. Relation of mitochondria-rich chloride cells to active chloride transport in the skin of a marine teleost. J. Exp. Zool., 214: 147-156.

Nie, N.H., Hull, C.H., Jenkins, J.G., Steinbrenner, K. and Bent., D.H., 1975. SPSS: Statistical Package for the Social Sciences. McGraw-Hill Book Company, New York, NY, 675 pp.

Nishioka, R.S., Young, G., Bern, H.A., Jochimsen, W. and Hiser, C., 1985. Attempts to intensify the thyroxin surge in coho and king salmon by chemical stimulation. Aquaculture, 45: 215-225.

Parry, G., 1960. The development of salinity tolerance in the salmon, Salmo salar (L.) and some related species. J. Exp. Biol., 37: 425-434.

Philpott, C.W. and Copeland, D.E., 1963. Fine structure of chloride cells from three species of Fundulus. J. Cell Biol., 18: 389-404.

Pisam, M., 1981. Membranous systems in the "Chloride Cell" of teleostean fish gill; their modifications in response to the salinity of the environment. Anat. Rec., 200: 401-414.

Prunet, P., Boeuf, G. and Houdebine, L.M., 1985. Plasma and pituitary prolactin levels in rainbow trout during adaptation to different salinities. J. Exp. Zool., 235: 187-196.

Sardet, C., 1980. Freeze fracture of the gill epithelium of euryhaline teleost fish. Am. J. Physiol., 238: R207-R212.

Sardet, C., Pisam, M. and Maetz, J., 1979. The surface epithelium of teleostean fish gills: cellular and junctional adaptations of the chloride cell in relation to salt adaptation. J. Cell Biol., 80: 96-117. 
Shirai, N. and Utida, S., 1970. Development and degeneration of the chloride cell during seawater and freshwater adaptation of the Japanese eel, Anguilla japonica. Z. Zellforsch. Mikrosk. Anat., 103: 247-264.

Specker, J.L. and Richman, N.H., III, 1984. Environmental salinity and the thyroidal response to thyrotropin in juvenile coho salmon (Oncorhynchus kisutch). J. Exp. Zool., 230: 329-333.

Threadgold, L.T. and Houston, A.H., 1964. An electron microscope study of the "chloride cell" of Salmo salar L. Exp. Cell Res., 34: 1-23.

Wedemeyer, G.A., Saunders, R.L. and Clarke, W.C., 1980. Environmental factors affecting smoltification and early marine survival of anadromous salmonids. Mar. Fish. Rev., 42: 1-14.

White, B.A. and Nicoll, C.S., 1981. Hormonal control of amphibian metamorphosis. In: L.I. Gilbert and E. Frieden (Editors), Metamurphusis: A Problem in Develupmental Biolugy. Plenum Press, New York, NY, pp. 363-396.

Wickes, E.G., Smith, L.T. and Meade, T.L., 1983. Changes in Keys-Willmer cell numbers in the gills of steelhead trout during smoltification. Prog. Fish-Cult., 45: 195-198.

Yamauchi, K., Ban, M., Kasahara, N., Izumi, T., Kojima, H. and Harako, T., 1985. Physiological and behavioral changes occurring during smoltification in the masu salmon, Oncorhynchus masou. Aquaculture, 45: 227-235.

Zaugg, W.S., 1982. A simplified preparation for adenosine triphosphatase determination in gill tissue. Can. J. Fish. Aquat. Sci., 39: 215-217. 